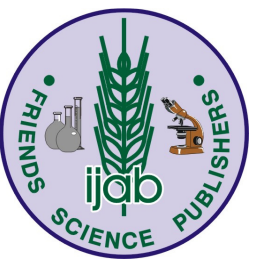

\title{
Alleviation of Nickel-Induced Stress in Mungbean through Application of Gibberellic Acid
}

\author{
Muhammad Asif Ali ${ }^{1}$, Hafiz Naeem Asghar ${ }^{1 *}$, Muhammad Yahya Khan ${ }^{1}$, Muhammad Saleem ${ }^{1}$, Muhammad Naveed ${ }^{1}$ \\ and Nabeel Khan Niazi ${ }^{1,2}$ \\ ${ }_{1}^{1}$ Institute of Soil and Environmental Sciences, University of Agriculture, Faisalabad, Faisalabad 38040, Pakistan \\ ${ }^{2}$ Southern Cross GeoScience, Southern Cross University, Lismore 2480, NSW, Australia \\ *For correspondence: naeemasghar@yahoo.com
}

\begin{abstract}
Nickel (Ni) is the most eco-toxic and harmful metal for soil biological activity, plant metabolism and health of animals and human beings. Elevated level of Ni in plants causes many nutritional and physiological disorders as well as perturbs in normal balance of phytohormones. Exogenous application of phytohormones can regulate plant growth and reduce inhibitory effect of toxic metals on plants. Therefore present study was conducted to assess the effect of Ni contamination on growth and yield of mungbean and role of gibberellic acid $\left(\mathrm{GA}_{3}\right)$ to counteract negative effects of $\mathrm{Ni}$ contamination. Mungbean seeds were sown in potted soil contaminated with different levels of $\mathrm{Ni}\left(0,20,40\right.$, and $\left.60 \mathrm{mg} \mathrm{kg}^{-1}\right)$. Two sets of Ni contamination levels were maintained, one set was kept without application of $\mathrm{GA}_{3}$ while in second set $10^{-4} \mathrm{M} \mathrm{GA}_{3}$ was applied as foliar spray at 15,30 and 45 days after germination. Significant reduction in all growth and yield attributes of mungbean was recorded in Ni contaminated pots. However, application of $\mathrm{GA}_{3}$ enhanced the length, fresh and dry weight of shoots and roots as well as grain yield of mungbean in $\mathrm{Ni}$ contamination. Moreover, Ni concentration was increased in roots and shoots of mungbean with increasing levels of $\mathrm{Ni}$ contamination from 0 to $60 \mathrm{mg} \mathrm{kg}$. But, application of $\mathrm{GA}_{3}$ caused significant decrease in $\mathrm{Ni}$ concentration in roots and shoots of mungbean in Ni contaminated soil. It is concluded that use of $\mathrm{GA}_{3}$ could be very effective to improve plant growth through reduced Ni uptake by plants in the Ni contaminated soils. (C) 2015 Friends Science Publishers
\end{abstract}

Keywords: Heavy metals; Reduction; Contamination; Phytohormones; Toxic; Mungbean

\section{Introduction}

Toxic metals' pollution is one of the major environmental issues. It leads to undesirable changes in physical, chemical and biological characteristics of air, water and soil, which adversely affect plants, animals and human beings (Samuel et al., 2014; Zhang et al., 2014). Nickel (Ni) is amongst the toxic metals and is considered as an essential element in traces for some species of animals, microorganisms and plants. However, its higher concentration in soil causes disturbance in normal metabolism of plants and toxicity symptoms (Ahmad et al., 2009; Ali et al., 2009). On an average, its concentration is 75 and $40 \mathrm{mg} \mathrm{kg}^{-1}$ in earth crust and soils, respectively. Major sources of $\mathrm{Ni}$ contamination in soil are agricultural waste, city effluents, impurities in fertilizers, bio-solids and burning of diesel oil (Pollard et al., 2014). The common symptoms of Ni phytotoxicity include inhibition of growth, seed germination and induction of chlorosis, necrosis and wilting (Leon et al., 2005; Ali et al., 2009; Ahmad et al., 2009). It causes oxidative stress in plants and interferes in photosynthetic activity and sugar transport mechanisms (Pandey and Sharma, 2002; Madhava
Rao and Sresty, 2000). Metals toxicity causes perturbation in normal balance of phytohormones i.e. auxins, gibberellins, cytokinins, abscisic acid and ethylene (Rademacher, 1990; Gangwar et al., 2011). Phytohormones also known as plant growth regulators (PGRs) are the main players for regulation of plant growth and development (Khalid et al., 2001; Ghaafar and Rawi, 2011; Sabir et al., 2013). They are key for plants to respond an ever changing environment and external stimuli (Halter et al., 2005) and mediate plant growth in their specific synergistic and/or antagonistic cross-talk (Ali et al., 2013; Gangwar et al., 2011). In response to abiotic stresses biosynthesis of abscisic acid (ABA) increases while the level of cytokinin (CK) and gibberellins (GA) decreases (Veselov et al., 2003). Gibberellins (GA) are the versatile phytohormones, which play important role in seed germination, stem elongations, leaf expansion and development of reproductive parts of plants (Ghaafar and Rawi, 2011). Gibberellic acid $\left(\mathrm{GA}_{3}\right)$ helps the plants to adapt abiotic stresses and has shielding effects against metals toxicity (Tuna et al., 2008; Maggio et al., 2010). Exogenous application of $\mathrm{GA}_{3}$ increases the biosynthesis of salicylic 
acid (SA) and improves abiotic stress tolerance of plant which could be correlated with increased endogenous levels of SA (Gangwar et al., 2011; Halter et al., 2005). Exogenously applied $\mathrm{GA}_{3}$ improves plant growth and development by modulating the endogenous levels of stress responsive phytohormones i.e. ABA and ethylene in abiotic stresses (Saeidi et al., 2005; Gangwar et al., 2011). Gibberellic acid improves plant growth, photosynthetic rate, sugar contents and antioxidant enzymatic activities of plants under heavy metal stress (Saeidi et al., 2005). Savita et al. (2010) examined that $\mathrm{GA}_{3}$ decreased the negative effects of $\mathrm{Ni}$ on peas and increased the seed germination, root and shoot growth in $\mathrm{Ni}$ contaminated soil. Exogenous application of $\mathrm{GA}_{3}$ strongly inhibits $\mathrm{Ni}$ and $\mathrm{Cd}$ assimilation into plant tissues and increases sugar contents in plants as well as alters the carbohydrate accumulation pattern in plant under $\mathrm{Cd}$ and/or Ni stress (Picazo and Moya, 2007). Keeping in view the role of gibberellic acid to alleviate stress induced negative changes in plants, the present study was conducted to assess the role of gibberellic acid $\left(\mathrm{GA}_{3}\right)$ to counteract the negative effects of $\mathrm{Ni}$ contamination on growth and yield of mungbeen.

\section{Materials and Methods}

A pot experiment was conducted in the wire house under ambient conditions to assess the effect of gibberellic acid $\left(\mathrm{GA}_{3}\right)$ on growth and yield of mungbean (Vigna radiate $\mathrm{L}$. var. AZRI-2006) in Ni contaminated soil. Sandy clay loam soil having EC $1.41 \mathrm{dS} \mathrm{m} \mathrm{m}^{-1}, \mathrm{pH} 7.5$, saturation percentage $37.5 \%$, organic matter $0.60 \%$, available phosphorous 7.30 $\mathrm{mg} \mathrm{kg}$, extractable potassium $129 \mathrm{mg} \mathrm{kg}^{-1}$ and $\mathrm{Ni}$ below detectable range was used to fill the pots. Prior to pot filling soil was contaminated by using $\mathrm{NiSO}_{4}$ salt as a source of $\mathrm{Ni}$ and finally four levels of $\mathrm{Ni}$ (0-no added $\mathrm{Ni}, 20,40$, and $60 \mathrm{mg} \mathrm{kg} \mathrm{kg}^{-1}$ ) contamination were maintained. Soil was allowed to equilibrate for two weeks after contamination with $\mathrm{Ni}$ and $10 \mathrm{~kg}$ soil was used to fill each pot lined with polyethylene sheet. Pots were irrigated with water before sowing and five seeds of mungbean were sown in each pot. After germination 3 plants were maintained in each pot by manual thinning. Two sets of $\mathrm{Ni}$ contamination levels were maintained, one set was kept without application of $\mathrm{GA}_{3}$ while in second set, $10^{-4} \mathrm{M} \mathrm{GA}_{3}$ was applied as foliar spray at 15,30 and 45 days after germination. Experiment was conducted by following completely randomized design with three replications. Recommended dose of NPK fertilizers $\left(22,65\right.$ and $\left.23 \mathrm{~kg} \mathrm{ha}^{-1}\right)$ in the form of urea, di-ammonium phosphate (DAP) and sulfate of potash (SOP), respectively was applied and full dose of $\mathrm{P}$ and $\mathrm{K}$ was applied before sowing while $\mathrm{N}$ was applied in two splits. Pots were irrigated with tap water as when needed. Crop was harvested at maturity (74 days after sowing) and data regarding growth parameters i.e. plant height, fresh and dry shoot weight, root length, fresh and dry root weight as well as yield parameters i.e. number of grains per plant and grain yield per plant were recorded. For $\mathrm{Ni}$ determination, mungbean plants were separated into roots and shoots. Plant samples were wet digested using $\mathrm{HNO}_{3}$ and $\mathrm{HClO}_{4}$ (Rashid, 1986). After the wet digestion, the amount of $\mathrm{Ni}$ was determined using an atomic absorption spectrophotometer (Perkin Elmer AAnalyst 100, USA) as described by Wickliffe et al. (1994). Data was analyzed statistically by using computer based statistical software Statistix-8.1 (Analytical Software, Tallahassee, USA). Means were compared by applying new Duncan's Multiple Range Test (DMRT) (Steel et al., 1997).

\section{Results}

Growth and yield attributes of mungbean were negatively affected at different levels of $\mathrm{Ni}$ contamination. However, the effect of various levels of $\mathrm{Ni}$ contamination was variable and reduction in growth and yield was increased by increasing levels of $\mathrm{Ni}$ contamination. Moreover, application of $\mathrm{GA}_{3}$ reversed the toxic effects of $\mathrm{Ni}$ contamination and improved all the growth and yield parameters under different levels of Ni contamination. Data (Table 1) revealed that shoot length was significantly reduced up to 27,36 and $66 \%$ at 20,40 and $60 \mathrm{mg} \mathrm{Ni} \mathrm{kg}$ of soil, respectively as compared to control plants where neither $\mathrm{GA}_{3}$ nor contamination were applied. But application of $\mathrm{GA}_{3}$ significantly increased the shoot length by 32,35 and $23 \%$ in Ni contamination of 20,40 and $60 \mathrm{mg}$ $\mathrm{kg}^{-1}$, respectively as compared to plants grown at same levels of contamination where no $\mathrm{GA}_{3}$ was applied. Results presented in Table 1 showed that Ni contamination of 20, 40 and $60 \mathrm{mg} \mathrm{kg}^{-1}$ significantly decreased the root length up to 21, 22 and $64 \%$, respectively as compared to control treatment. The root length was significantly increased by the application of $\mathrm{GA}_{3}$ up to 23, 13 and $14 \%$ in $\mathrm{Ni}$ contamination of 20,40 and $60 \mathrm{mg} \mathrm{kg}^{-1}$, respectively as compared to plants grown at same levels of contamination without $\mathrm{GA}_{3}$ application.

Data (Table 1) showed that reduction in shoot fresh weight up to 36,47 and $74 \%$ was observed by of 20,40 and $60 \mathrm{mg} \mathrm{kg}^{-1}$ of $\mathrm{Ni}$ contamination, respectively as compared to treatment without contamination (control). But $\mathrm{GA}_{3}$ improved the shoot fresh weight up to 17,24 and $32 \%$ in $\mathrm{Ni}$ contamination of 20,40 and $60 \mathrm{mg} \mathrm{kg}^{-1}$, respectively as compared to plants grown under contamination, where no $\mathrm{GA}_{3}$ was applied. The shoot dry weight (Table 1) was significantly reduced by 36,46 and $75 \%$ under $\mathrm{Ni}$ contamination of 20,40 and $60 \mathrm{mg} \mathrm{kg}^{-1}$, respectively as compared to plants grown in control (neither $\mathrm{GA}_{3}$ nor contamination). However, shoot dry weight was significantly increased up to 26,22 and $29 \%$ by application of $\mathrm{GA}_{3}$ in $\mathrm{Ni}$ contamination of 20,40 and $60 \mathrm{mg} \mathrm{kg}^{-1}$, respectively as compared to plants grown where no $\mathrm{GA}_{3}$ was applied.

Data regarding root fresh weight (Table 2) revealed 
Ali et al. / Int. J. Agric. Biol., Vol. 17, No. 5, 2015

Table 1: Effect of gibberellic acid on shoot parameters of mungbean in Ni contamination

\begin{tabular}{|c|c|c|c|c|c|c|}
\hline \multirow[t]{2}{*}{ Treatments } & \multicolumn{2}{|c|}{ Shoot length $(\mathrm{cm})$} & & hoot fresh v & \multicolumn{2}{|c|}{ Shoot dry weight $(\mathrm{g})$} \\
\hline & Without $\mathrm{GA}_{3}$ & With $\mathrm{GA}_{3}$ & Without $\mathrm{GA}_{3}$ & With $\mathrm{GA}_{3}$ & Without $\mathrm{GA}_{3}$ & With $\mathrm{GA}_{3}$ \\
\hline Control & $38.7 \mathrm{~b}$ & $49.7 \mathrm{a}$ & $21.7 \mathrm{~b}$ & $24.7 \mathrm{a}$ & $9.1 \mathrm{~b}$ & $11.1 \mathrm{a}$ \\
\hline $\mathrm{Ni}\left(20 \mathrm{mg} \mathrm{kg}^{-1}\right)$ & $28.3 \mathrm{~d}$ & $37.3 \mathrm{~b}$ & $13.7 \mathrm{~d}$ & $16 \mathrm{c}$ & $5.7 \mathrm{~d}$ & $7.2 \mathrm{c}$ \\
\hline $\mathrm{Ni}\left(40 \mathrm{mg} \mathrm{kg}^{-1}\right)$ & $24.7 \mathrm{e}$ & $33.3 \mathrm{c}$ & $11.5 \mathrm{e}$ & $14.3 \mathrm{~d}$ & $4.6 \mathrm{e}$ & $5.9 \mathrm{~d}$ \\
\hline $\mathrm{Ni}\left(60 \mathrm{mg} \mathrm{kg}^{-1}\right)$ & $13.3 \mathrm{~g}$ & $16.3 \mathrm{f}$ & $5.7 \mathrm{f}$ & $7.5 \mathrm{f}$ & $2.3 \mathrm{~g}$ & $2.9 \mathrm{f}$ \\
\hline
\end{tabular}

Data is mean of three repeats

Means sharing the same letter(s) do not differ significantly at $p \leq 0.5$

Table 2: Effect of gibberellic acid on root parameters of mungbean in Ni contamination

\begin{tabular}{|c|c|c|c|c|c|c|}
\hline \multirow[t]{2}{*}{ Treatments } & \multicolumn{2}{|c|}{ Root length $(\mathrm{cm})$} & \multicolumn{2}{|c|}{ Root fresh weight $(\mathrm{g})$} & \multicolumn{2}{|c|}{ Root dry weight (g) } \\
\hline & Without $\mathrm{GA}_{3}$ & With $\mathrm{GA}_{3}$ & Without $\mathrm{GA}_{3}$ & With $\mathrm{GA}_{3}$ & Without $\mathrm{GA}_{3}$ & With $\mathrm{GA}_{3}$ \\
\hline Control & $17 \mathrm{~b}$ & $22.4 \mathrm{a}$ & $4.5 \mathrm{~b}$ & $5.5 \mathrm{a}$ & $1.7 \mathrm{~b}$ & $2.3 \mathrm{a}$ \\
\hline $\mathrm{Ni}\left(20 \mathrm{mg} \mathrm{kg}^{-1}\right)$ & $13.4 \mathrm{~d}$ & $14.9 \mathrm{bc}$ & $3.3 \mathrm{~d}$ & $4.4 \mathrm{bc}$ & $1.2 \mathrm{~d}$ & $1.6 \mathrm{~b}$ \\
\hline $\mathrm{Ni}\left(40 \mathrm{mg} \mathrm{kg}^{-1}\right)$ & $6.3 \mathrm{~d}$ & $7.2 \mathrm{~cd}$ & $3 \mathrm{~d}$ & $4.1 \mathrm{c}$ & $1.0 \mathrm{e}$ & $1.5 \mathrm{c}$ \\
\hline $\mathrm{Ni}\left(60 \mathrm{mg} \mathrm{kg}^{-1}\right)$ & $16.5 \mathrm{e}$ & $4.2 \mathrm{e}$ & $1.3 \mathrm{e}$ & $1.5 \mathrm{e}$ & $0.4 \mathrm{f}$ & $0.6 \mathrm{f}$ \\
\hline
\end{tabular}

Data is mean of three replicates

Means sharing the same letter(s) do not differ significantly at $p \leq 0.5$

that $\mathrm{Ni}$ contamination decreased the root fresh weight by 27,33 and $71 \%$, respectively as compared to plants grown in control (neither $\mathrm{GA}_{3}$ nor contamination). However, increase in root fresh weight upto 33, 37 and 15\% was observed by application of $\mathrm{GA}_{3}$ at $\mathrm{Ni}$ contamination of 20, 40 and $60 \mathrm{mg} \mathrm{kg}^{-1}$, respectively as compared to plants grown where no $\mathrm{GA}_{3}$ was applied. Decrease in root dry weight up to 29,41 and $74 \%$ was recorded at 20,40 and 60 $\mathrm{mg} \mathrm{kg}{ }^{-1}$ of $\mathrm{Ni}$ concentration, respectively as compared control where neither $\mathrm{GA}_{3}$ nor $\mathrm{Ni}$ was applied. Nevertheless, application of $\mathrm{GA}_{3}$ significantly increased the root dry weight up to 38,45 and $22 \%$ in $\mathrm{Ni}$ contamination of 20,40 and $60 \mathrm{mg} \mathrm{kg}^{-1}$, respectively as compared to plants grown at same levels of $\mathrm{Ni}$ contamination without application of $\mathrm{GA}_{3}$.

Number of grains per plant were significantly decreased at all levels of Ni contamination as compared to plants grown without $\mathrm{Ni}$ stress (Table 3). However, $\mathrm{GA}_{3}$ improved the number of grains per plant in $\mathrm{Ni}$ contaminated soil as compared to plants growth in $\mathrm{Ni}$ contaminated soil without application of $\mathrm{GA}_{3}$. It was observed that the grains weight per plant of mungbean was significantly decreased by 22, 31 and $51 \%$, under $\mathrm{Ni}$ contamination of 20,40 and 60 $\mathrm{mg} \mathrm{kg}{ }^{-1}$, respectively when compared with plants grown in control (where neither $\mathrm{GA}_{3}$ nor Ni contamination) (Table 3). The grains weight of mungbean significantly improved up to 13,29 and $20 \%$, at $\mathrm{Ni}$ contamination of 20,40 and $60 \mathrm{mg} \mathrm{kg}^{-}$ 1 , respectively by application of $\mathrm{GA}_{3}$ as compared to plants grown in Ni contamination where no $\mathrm{GA}_{3}$ was applied.

Data presented in Table 4 show that $\mathrm{GA}_{3}$ application was effective for decreasing $\mathrm{Ni}$ concentration in roots of mungbean. The application of $\mathrm{GA}_{3}$ decreased the toxic effects of $\mathrm{Ni}$ on mungbean crop. Ni contents in root were significantly decreased by 34,38 and $25 \%$, with the application of $\mathrm{GA}_{3}$ at 20,40 and $60 \mathrm{mg} \mathrm{kg}$ of $\mathrm{Ni}$ contamination as compared roots of plants grown at same levels of $\mathrm{Ni}$ contamination but without application of $\mathrm{GA}_{3}$.
Data regarding plant shoot analysis revealed that $\mathrm{Ni}$ concentration was significantly decreased with $\mathrm{GA}_{3}$ application up to 31,24 and $25 \%$ at $\mathrm{Ni}$ contamination of 20 , 40 and $60 \mathrm{mg} \mathrm{kg}^{-1}$, respectively as compared plants grown in $\mathrm{Ni}$ contamination where no $\mathrm{GA}_{3}$ was applied.

\section{Discussion}

Nickel is a widely distributed metal in the environment and is a potentially toxic metal that negatively affects agricultural soils, plants, animals as well as in humans. The higher concentration of $\mathrm{Ni}$ in the plants can cause many nutritional and physiological disorders (Vinterhalter and Vinterhalter, 2005). $\mathrm{Ni}$ is considered to be an essential micronutrient for various plants (Vogel-Mikus et al., 2005). However, higher concentration of this metal becomes toxic for the plant species. Effect of Ni contamination on plant growth inhibition has been reported by many researchers (Parida et al., 2003; Vinterhalter and Vinterhalter, 2005).

Results of our study showed that Ni contamination significantly decreased the mungbean growth and yield. Nickel stress caused reduction in shoot length, root length, shoot fresh weight, shoot dry weight, root fresh weight, root dry weight, number of grains per plant and grain weight per plant as compared to plants grown in pots without stress (control). This decrease in growth and yield attributes of mungbean might be attributed to inhibition of chlorophyll biosynthesis due to $\mathrm{Ni}$ toxicity that creates nutrient imbalance by replacing $\mathrm{Mg}^{+2}$ ions (Pandey and Sharma, 2002). Nickel phytotoxicity also decreases photosynthetic pigments (Ahmad et al., 2007), chlorophyll content (Wani et al., 2007) and induces oxidative stress (Kumar et al., 2012), which might be the reasons of decreased growth and yield of mungbean. It is clearly evident from the work of other scientists that $\mathrm{Ni}$ toxicity decreases the tissue water contents, nutrient uptake, iron transport and causes mitotic 
Table 3: Effect of gibberellic acid on yield parameters of mungbean in Ni contamination

\begin{tabular}{lllll}
\hline Treatments & \multicolumn{2}{c}{ Number of grains plant } & \multicolumn{2}{c}{ Grains weight plant $^{-1}(\mathrm{~g})$} \\
\cline { 2 - 5 } & Without $\mathrm{GA}_{3}$ & With GA & Without GA & With $\mathrm{GA}_{3}$ \\
\hline Control & $64 \mathrm{~b}$ & $76.3 \mathrm{a}$ & $1.02 \mathrm{~b}$ & $1.32 \mathrm{a}$ \\
$\mathrm{Ni}\left(20 \mathrm{mg} \mathrm{kg}^{-1}\right)$ & $41.7 \mathrm{e}$ & $59 \mathrm{c}$ & $0.8 \mathrm{~d}$ & $0.9 \mathrm{bc}$ \\
$\mathrm{Ni}\left(40 \mathrm{mg} \mathrm{kg}^{-1}\right)$ & $33.3 \mathrm{f}$ & $50.7 \mathrm{~d}$ & $0.7 \mathrm{~d}$ & $0.9 \mathrm{c}$ \\
$\mathrm{Ni}\left(60 \mathrm{mg} \mathrm{kg}^{-1}\right)$ & $18.3 \mathrm{~h}$ & $28.7 \mathrm{~g}$ & $0.5 \mathrm{f}$ & $0.6 \mathrm{e}$ \\
\hline
\end{tabular}

Data is mean of three replicates

Means sharing the same letter(s) do not differ significantly at $p \leq 0.5$

Table 4: Effect of gibberellic acid on Ni concentration in root and shoot of mungbean in Ni contamination

\begin{tabular}{lllll}
\hline \multirow{2}{*}{ Treatments } & \multicolumn{4}{c}{ Ni Concentration $\left(\mu \mathrm{g} \mathrm{g}^{-1}\right)$} \\
\cline { 2 - 5 } & \multicolumn{3}{c}{ Roots } & \multicolumn{2}{c}{ Shoots } \\
\cline { 2 - 5 } & Without GA 3 & With GA & Without GA & With $\mathrm{GA}_{3}$ \\
\hline Control & $6.8 \mathrm{~g}$ & $3.9 \mathrm{~h}$ & $3.3 \mathrm{~g}$ & $2.1 \mathrm{~h}$ \\
$\mathrm{Ni}\left(20 \mathrm{mg} \mathrm{kg}^{-1}\right)$ & $15.9 \mathrm{~d}$ & $10.4 \mathrm{f}$ & $7.8 \mathrm{~d}$ & $5.4 \mathrm{f}$ \\
$\mathrm{Ni}\left(40 \mathrm{mg} \mathrm{kg}^{-1}\right)$ & $19.8 \mathrm{c}$ & $12.4 \mathrm{f}$ & $10.1 \mathrm{c}$ & $7.7 \mathrm{e}$ \\
$\mathrm{Ni}\left(60 \mathrm{mg} \mathrm{kg}^{-1}\right)$ & $29.4 \mathrm{a}$ & $22 \mathrm{~b}$ & $14.5 \mathrm{a}$ & $10.9 \mathrm{~b}$ \\
\hline
\end{tabular}

Means sharing the same letter(s) do not differ significantly at $p \leq 0.5$

inhibition (Gajewaska et al., 2006; Saito et al., 2010), which might result in decreased growth and yield of mungbean. Furthermore, reduced photosynthetic and transpiration activities (Ouzounidou et al., 2006) and decreased enzymatic and antioxidant activities (Dubey and Pandey, 2011) due to $\mathrm{Ni}$ stress could also be the reason of decreased growth and yield of mungbean in $\mathrm{Ni}$ contamination. The plants grown on contaminated soil accumulates metal contents, which result in restricted growth of plants due to alterations in normal biochemical and physiological process like protein penetration, inhibition of enzyme activity, and impaired nutrition etc. (Arun et al., 2005).

The improvement in plant growth and yield attributes in $\mathrm{Ni}$ contamination by $\mathrm{GA}_{3}$ application might be due to involvement of $\mathrm{GA}_{3}$ in regulation of various physiological and biochemical process of plants. It is reported that $\mathrm{GA}_{3}$ increases total protein contents, total nitrogen contents, nitrate reductase activity, ammonium assimilating enzyme activity and increases the activities of glutathione reductase and dehydro reductase activities that might involve in enhancement of glutathione and ascorbate (Noctor and Foyer, 1998). Glutathione and ascorbate are antioxidants that play important role in scavenging of reactive oxygen species and prevent oxidative stress in plants (Noctor and Foyer, 1998; Saeidi et al., 2005). Moreover $\mathrm{GA}_{3}$ increases root biomass, shoot biomass, photosynthesis, water uptake, chlorophyll content, nutrient uptake and root length (Saeidi et al., 2005; Gangwar et al., 2011). The abiotic stresses cause disturbance in the normal balance of hormones of plants (Iqbal and Ashraf, 2013) and most likely $\mathrm{GA}_{3}$ application regulated the hormonal balance of mungbean plants in Ni contaminated soil, which might be resulted in improved mungbean growth and yield. Moreover, Siddiqui et al. (2011) stated that the interactive effect of $\mathrm{GA}_{3}$ with $\mathrm{Ca}^{2+}$ alleviates $\mathrm{Ni}$ toxicity in plants by the induction of antioxidative enzymes and proline accumulation, which might result in improved growth and yield of plants in $\mathrm{Ni}$ stressed soils.

Decrease in Ni concentration in root and shoot of mungbean plant by the application of $\mathrm{GA}_{3}$ in $\mathrm{Ni}$ contaminated soil might be due to involvement of $\mathrm{GA}_{3}$ in alteration of membrane permeability which affects the membrane transport processes like metals uptake (Rubio et al., 1994; Picazo and Moya, 2007). Data regarding decrease in concentration of $\mathrm{Ni}$ in plants can be correlated with findings of Picazo and Moya (2007). They concluded that the application of $\mathrm{GA}_{3}$ strongly inhibits $\mathrm{Ni}$ and $\mathrm{Cd}$ assimilation into plant and increases sugar contents in leaves, roots, and also changes carbohydrate accumulation pattern in plant.

\section{Conclusion}

Gibberellic acid $\left(\mathrm{GA}_{3}\right)$ increased the growth and yield of mungbean plant grown in normal soil as well as on contaminated soils. The application of $\mathrm{GA}_{3}$ decreased the toxic effect of $\mathrm{Ni}$ on plant and improved the biomass of plant and reduced the concentration of $\mathrm{Ni}$ in plants. This approach could be very effective to reduce $\mathrm{Ni}$ uptake in plants in the Ni polluted soil but further work is needed to know the exact mechanism involved.

\section{References}

Ahmad, M.S.A., M. Hussain, M. Ashraf, R. Ahmad and M.Y. Ashraf, 2009. Effect of nickel on seed germinability of some elite sunflower (Helianthus annus L.). Pak. J. Bot., 41: 1871-1882

Ahmad, M.S.A., M. Hussain, R. Saddiq and A.K. Alvi, 2007. Mungbean: A nickel indicator, accumulator or excluder. B. Environ. Cont. Toxicol., 78: 319-324

Ali, M.A., M. Ashraf and H.R. Athar, 2009. Influnce of nickel stress on growth and some important physiological/biochemical attributes in some diverse canola cultivars. J. Hazard. Mater., 172: 964-969

Ali, T., S. Mahmood, M.Y. Khan, A. Aslam, M.B. Hussain, H.N. Asghar and M.J. Akhtar, 2013. Phytoremediation of cadmium contaminated soil by auxin assisted bacterial inoculation. Asian J. Agric. Biol., 1: $79-84$

Arun, K.S., C. Cervantesb, H. Loza-Taverac and S. Avudainayagamd, 2005. Chromium toxicity in plants. Environ. Int., 31: 7390-753

Baralkiewicz, D. and J. Siepak, 1999. Chromium, nickel and cobalt in environmental samples and existing legal norms. Polish J. Environ., 8: 201-208

Dubey, D. and A. Pandey, 2011. Effect of Nickel (Ni) on chlorophyll, lipid peroxidation and antioxidant enzymes activities in black gram (Vigna mungo) leaves. Int. J. Sci. Nat., 2: 395-401

Gajewska, E., M. Sklodowska, M. Slaba and J. Mazur, 2006. Effect of nickel on antioxidative enzyme activities, proline and chlorophyll contents in wheat shoots. Biologia. Plantarum., 50: 653-659

Gangwar, S., V.P. Singh, P.K. Srivastava and J.N. Maurya, 2011. Modification of chromium (VI) phytotoxicity by exogenous application of Gibberellic acid Pisum sativum (L) seedlings. Acta. Physiol. Plant., 33: 1385-1397

Ghaafar, A.C. and I.M.T. Rawi, 2011. Response of mungbean (Vigna radiata $\mathrm{L} .$, Wilczek) to gibberellic acid rates and varying irrigation frequencies. Int. J. Biol. Sci., 1: 85-92 
Halter, L., R. Habegger and W.H. Schnitzler, 2005. Gibberellic acid on artichoke (Cynara scolymus L.) cultivated in Germany to promote earliness and to increase productivity. Acta Hort., 681: 75-81

Iqbal, M. and M. Ashraf, 2013. Gibberellic acid mediated induction of salt tolerance in wheat plants: Growth, ionic partitioning, photosynthesis, yield and hormonal homeostasis. Environ. Exp. Bot., 86: 76-85

Khalid, A., M. Arshad, Z.A. Zahir and M. Khalid, 2001. Relative efficiency of rhizobacteria for auxin biosynthesis. J. Biol. Sci., 1: 750-754

Kumar, H., D. Sharma and V. Kumar, 2012. Nickel-induced oxidative stress and the role of antioxidant defence in barley roots and leaves. Int. J. Environ. Biol., 2: 121-128

Leon, V., J. Rabier, R. Notonier, R. Barthelemy, X. Moreau, S. BouraimaMadjebi, J. Viano and R. Pineau, 2005. Effect of three nickel salts on germinating seed of Grevillea exul var. rubiginosa, an endemic serpentine Proteaceae. Ann. Bot., 95: 609-618

Madhava, R. and K.V.S. Sresty, 2000. Antioxidative parameters in the seedling of pigeonpe (Cajanus cajan (L.) Millspaugh) in response to Zn and Ni stress. Plant Sci., 157: 113-128

Maggio, A., G. Barbieri, G. Raimondi and S.D. Pascale, 2010. Contrasting effects of GA3 treatments on tomato plants exposed to increasing salinity. J. Plant Growth Regul., 29: 63-72

Noctor, G. and C.H. Foyer, 1998. Ascorbate and glutathione: keeping active oxygen under control. Annu. Rev. Plant Physiol. Plant Mol. Biol., 49: 249-279

Ouzounidou, G., M. Moustakas, L. Symeonidis and S. Karataglis, 2006. Response of wheat seedlings to $\mathrm{Ni}$ stress: effects supplemental calcium. Arch Environ. Contam. Toxicol., 50: 346-352

Pandey, N. and C.P Sharma, 2002. Effect of heavy metals $\mathrm{Co} 2+, \mathrm{Ni}^{2+}$ and $\mathrm{Cd}^{2+}$ on growth and metabolism of cabbage. Plant Sci., 163: 753-758

Parida, B.K., I.M. Chhibba and V.K. Nayyar, 2003. Influence of nickel contaminated soils on fenugreek growth and mineral composition. Sci. Hortic., 98: 113-119

Picazo, I. and J.L. Moya, 2007. Heavy metal hormone interactions in rice plants: effect on growth, photosynthesis and carbohydrate distribution. J. Plant Growth Regul., 14: 61-67

Pollard, A.J., R.D. Reeves and A.J.M. Baker, 2014. Facultative hyperaccumulation of heavy metals and metalloids. Plant Sci., 218: $8-17$

Rademacher, W., 1990. New types of plant growth retardants. In: Additional Perspectives for Practical Applications in Agriculture and Horticulture, pp: 611-618. Pharis, R.P. and S.B. Rood (eds.) Plant Growth Substances. Springer Verlag, Berlin

Rashid, A., 1986. Mapping zinc fertility of soils using indicator plants and soils analysis. PhD. Dissertation, University of Hawaii, HI, USA

Rubio, M.J., I. Escrig, M. Cortina, F.J. Loez-Benet and A. Snaz, 1994 Cadmium and nickel accumulation in rice plants. Effects on mineral nutrition and possible interactions of abscisic and gibberellic acids. Plant Growth Regul., 14: 151-157
Sabir, S., H.N. Asghar, S.U.R. Kashif, M.Y. Khan and M.J. Akhtar, 2013. Synergistic effect of plant growth promoting rhizobacteria and kinetin on maize. J. Anim. Plant Sci., 23: 1750-1755

Saeidi, S., R.A. Khavari, H. Fahimi, M. Ghorbanli and A. Majd, 2005. Amelioration of Ni toxicity in soybean, Plants by gibberellin and ascorbic acid. Rostaniha, 6: 21-27

Saito, A., M. Saito, Y. Ichikawa, M. Yoshiba, T. Tadano, and E. Miwa, 2010. Difference in the distribution and speciation of cellular nickel between nickel-tolerant and non-tolerant Nicotiana tabacum L. Plant Cell Environ., 33: 174-187

Samuel, J., Chikile and R. Sharma, 2014. Bioaccumulation of heavy metals in Soybean (Glycine $\max (\mathrm{L})$ Merr). Ind. J. Appl. Pure Biol., 29: 165-170

Savita, R.T. Shasthree, Sudhakar and B. Mallaiah, 2010. High frequency of plantlet regeneration and multiple shoot induction from leaf and stem explant of Citrullus colosynthis (L.), and endangered medicinal cucurbit. Int. J. Pharma Biol. Sci., 6: 1-8

Siddiqui, M.H., M.H. Al-Whaibi and M.O. Basalah, 2011. Interactive effect of calcium and gibberellin on nickel tolerance in relation to antioxidant systems in Triticum aestivum L. Protoplasma, 248: 503-511

Steel, R.G.D., J.H. Torrie and D.A. Dicky, 1997. Principals and Procedures of Statistics: A Biometrical Appraoch, $3^{\text {rd }}$ edition. McGraw Hill Book Int. Co., Singapore

Tuna, A., L. Kaya, C. Dikilitas, D.M. Higgs, 2008. The combined effects of gibberellic acid and salinity on some antioxidant enzyme activities, plant growth parameters and nutritional status in maize plants. Environ. Exp. Bot., 62: 1-9

Veselov, D., G. Kudoyarova, M. Symonyan and S. Veselov, 2003. Effect of cadmium on ion uptake, transpiration and cytokinin content in wheat seedlings. Bulg. J. Plant Physiol., 353-359

Vinterhalter, B. and D. Vinterhalter, 2005. Nickel hyperaccumulation in shoot cultures of Alyssum markgrafii. Biol. Plant., 49: 121-124

Vogel-Mikus, K., D. Drobne and M. Regvar, 2005. Zn, Cd and $\mathrm{Pb}$ accumulation and arbuscular mycorrhizal colonization of pennycress Thlaspi praecox Wulf. (Brassicaceae) from the vicinity of a lead mine and smelter in Slovenia. Environ. Pollut., 133: 233-242

Wani, P.A., M.S. Khan and A. Zaidi, 2007. Impact of heavy metal toxicity on plant growth, symbiosis, seed yield and nitrogen and metal uptake in chickpea. Aust. J. Exp. Agric., 47: 712-720

Wickliffe, M.E., S. Salih and J.E Lawler, 1994. Atomic transition probabilities in RuI. J. Quant. Spectrosc. Ra., 51: 545-556

Zhang, Q., V. Achal, W.N. Xiang and D. Wang, 2014. Identification of heavy metal resistant bacteria isolated from yangtze river, China. Int J. Agric. Biol., 16: 619-623

(Received 17 September 2014; Accepted 03 January 2015) 